\title{
The possible role of the cyclopoid copepod Oithona in retarding vertical flux of zooplankton faecal material
}

\author{
Humberto E. González, Victor Smetacek
}

Alfred-Wegener-Institute for Polar and Marine Research, Am Handelshafen 12, D-27570 Bremerhaven, Germany

\begin{abstract}
Cyclopoid copepods of the cosmopolitan genus Oithona are often the most abundant metazooplankton in both coastal and oceanic waters. Reasons for their ubiquity have been discussed but their feeding habits are not well known. Field observations and results from experiments presented here suggest that Oithona is also coprophagous. Data collected along the eastern shelf of Svalbard (Spitsbergen, Norway) during ice retreat showed that Oithona was the most abundant metazooplankter and a negative correlation between calanoid faecal material (volume) in the water column and Oithona abundance was found, but there was no significant relationship between calanoids and their faeces. In experiments in which calanoid copepods were confined together with Oithona, the latter always removed and presumably ingested a significant amount of calanoid faecal material at rates that appeared independent of ambient food concentrations. About 20 to $30 \%$ of the calculated daily carbon requirements of Oithona could have been met from faecal matter. We speculate that Oithona uses chemical cues to find and intercept sinking faecal matter in the water column and that its ability to use this ubiquitous food source efficiently is one of the reasons underlying its extraordinarily widespread occurrence. Although it has been shown that generally only a small percentage of calanoid faeces produced in the surface layer contributes to vertical flux, little is known about the fate of the 'missing' faeces. We argue that metazoans are mainly responsible for retention of faecal material in the surface layer and that cyclopoid copepods are an important part of this 'coprophagous filter' that retards vertical flux in the water column.
\end{abstract}

KEY WORDS: Zooplankton faeces - Oithona Coprophagy - Vertical flux - Barents Sea

\section{INTRODUCTION}

Species of the cyclopoid copepod genus Oithona are probably the most abundant metazooplankton in a wide variety of eutrophic and oligotrophic marine habitats ranging from the poles to the tropics and from open oceanic to shallow, coastal regimes (see review by Paffenhöfer 1993). Indeed, as Oithona species are very similar in appearance, they represent probably the most wide-spread and ubiquitous morphotype group amongst marine metazooplankton. Paffenhöfer (1993) has raised and addressed the question why Oithona is so successful in such disparate environments. He lists the following reasons to explain its ubiquity: (1) sluggish behaviour, hence low metabolic expenditure, enables it to survive and even produce eggs at low food availability; and (2) female longevity coupled with extended reproductive periods and with nauplii hatching from attached egg-sacs serve to maintain its presence in the water column for longer periods than other metazooplankters with life cycles geared to local seasonality in food supply.

The reasons underlying the apparent success of the Oithona morphotype are not clear. On the basis of raptorial mouth parts, laboratory feeding experiments and gut content analyses, Oithona has been variously termed carnivorous, herbivorous or omnivorous (Gauld 1966, Turner 1986, Paffenhöfer 1993 and references therein). Lampitt \& Gamble (1982) suggested that Oithona also feeds on detritus. The structure of the mouth parts coupled with sluggishness would restrict the genus to collection of either immobile or slow- 
moving particles larger than ca $6 \mu$ m (Lampitt 1978). Faecal pellets of other zooplankters fit this description nicely; since this particle type is almost as ubiquitous as Oithona itself, it follows that faeces could well be an important item in its diet.

Zooplankton faeces have long been considered as the major component of vertical particle flux because they are produced in large quantities and have high sinking rates (Turner \& Ferrante 1979, Angel 1984). However, field evidence indicates that only a small percentage of the pellets produced contributes to vertical flux; indeed, copepod feeding actually aids in retaining biogenic substances in the surface layer (Paffenhöfer \& Knowles 1979, Smetacek 1980, Peinert et al. 1989). Retention in surface layers rather than sinking as the main fate of crustacean faeces has been attributed to coprophagy (Smetacek 1980); additional mechanisms reducing sinking rates of faecal material suggested by Lampitt et al. (1990) and Noji et al. (1991) are fragmentation and loosening of faecal pellets by copepods (coprorhexy and coprochaly respectively).

In this paper we postulate that the ubiquitous cyclopoid genus Oithona is a major agent in retaining zooplankton faeces, in particular of calanoid copepods, in the surface layer. If Oithona is able to subsist as an opportunistic scavenger in marine pelagic systems, its universal presence could be explained by its successful adaptation to this universally prevalent niche. To test this hypothesis we followed the fate of calanoid copepod faecal pellets in the presence and absence of $O$. similis in ship-board experiments and carried out field observations along the eastern Svalbard shelf (Spitsbergen. Norway) to monitor pellet stocks in rela- tion to population size of zooplankton. We argue here that our results do not falsify the above hypotheses although comparable information from other regions is necessary before we can more thoroughly understand the reasons for (1) the extraordinary ubiquity of the genus Oithona and (2) the remarkable efficiency with which copepod faeces are retained in surface layers.

\section{MATERIALS AND METHODS}

Study sites. Field observations were carried out along a longitudinal transect $\left(30^{\circ} \mathrm{E}\right)$ in the northern Barents Sea from 16 to 27 July 1991 that crossed the eastern shelf of Svalbard (Spitsbergen) on the ARK VIII/2 cruise of RV 'Polarstern' (20 June to 30 July 1991, EPOS II Leg 2) (Fig. 1a). The experiments on coprophagy by calanoid and cyclopoid copepods were conducted during this cruise but also during the time station of the International Coccolithophorid Study on board RV 'Pelagia' in the Bjørnafjorden $\left(60^{\circ} 07^{\prime} \mathrm{N}\right.$, $5^{\circ} 40^{\prime}$ W), Norway, in April-May 1992 (Fig. 1b). Field observations from this latter cruise have been reported elsewhere (González et al. 1994) and are not of consequence for the questions addressed here.

Field observations. Mesozooplankton were sampled in the upper $100 \mathrm{~m}$ of the water column by vertical tows $\left(1 \mathrm{~m} \mathrm{~s}^{-1}\right)$ with a WP2 (200 $\mu \mathrm{m}$ mesh size) and cyclopoids and mesozooplankton faeces with a $50 \mu \mathrm{m}$ mesh size conical net. Both nets were equipped with an opening/closing system which enabled sampling of specific depth layers. Samples were preserved in buffered formalin ( $4 \%$ end concentration). Zooplank-

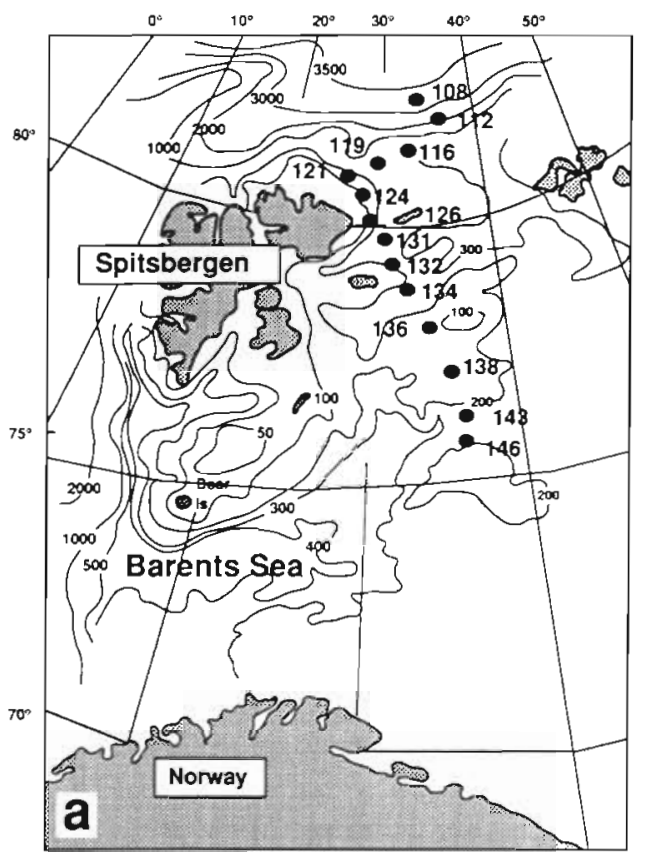

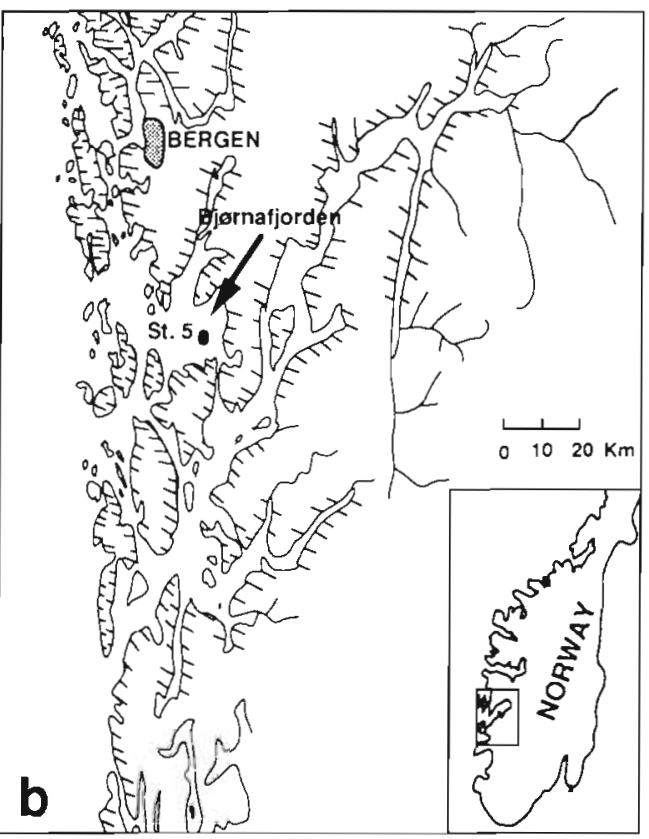

Fig. 1. (a) Location of the transect conducted during EPOS II along the eastern shelf of Svalbard, Spitsbergen, Norway. (b) Position of the time $\operatorname{Stn} 5$ (arrow) in the Bjørnafjorden, Norway 
ton were counted in major groups (cyclopoid and calanoid copepods, larvaceans) under a stereomicroscope (Wild M8). As the elongated calanoid copepod faeces were often broken due to mechanical stress during collection, the fragments were counted in size classes and volumes subsequently calculated. Hence pellet numbers could not be recorded precisely. However, the compact ellipsoid larvacean faeces were only counted in size classes of whole faeces as they did not break up into recognisable fragments; faecal volumes were also calculated for comparison with calanoid faecal material. On average 219 faeces were counted and measured per station (range 26 to 845 faeces from Stns 143 and 119 respectively). Depth distribution of faeces was recorded from 4 hauls over 24 h at Stn 124.

A cylindrical Monaco-type sediment trap (2 $\mathrm{m}$ high, $0.4 \mathrm{~m}$ diameter) was deployed in a drifting mode for $24 \mathrm{~h}$ at Stns 108, 112 and 124. The trap was located at $100 \mathrm{~m}$ depth. Faecal matter collected in the jar was counted and sized under an inverted microscope. As faeces suspended in the water column were collected with a $50 \mu \mathrm{m}$ mesh net, which will have lost the smaller fragments, this method will underestimate faeces volume when compared with the trap collections.

$\mathrm{C}$ and $\mathrm{N}$ content of zooplankton faeces. Calanus finmarchicus, C. glacialis and larvaceans from waters off Svalbard and a mixture of copepods and larvaceans from the Bjørnafjorden collected with a Bongo net, were placed immediately in filtered seawater and allowed to defecate for a few hours. Calanoid faeces were easy to distinguish from those of larvaceans. Because catches off Svalbard were dominated by either one of the above calanoid species, faeces could be referred to specifically. The catches from Bjornafjorden were a mixture of $C$. finmarchicus and Temora longicornis. For each measurement, about 100 to 200 of the larger, intact, freshly produced faeces were sized, rinsed in filtered seawater, collected on a precombusted GF/C filter and stored at $-30^{\circ} \mathrm{C}$ for 2 mo prior to analysis. Carbon and nitrogen of faeces from the Barents Sea were measured with a Carlo Erba Carbon and Nitrogen Analyzer 1500, with acetanilide as standard, whereas those from Bjørnafjorden were analysed by wet persulphate oxidation using a $0524 \mathrm{~B}$ Total Carbon System of Oceanography International (Cadée 1982).

Experiments with calanoid and cyclopoid copepods. Copepods were collected with a Bongo net and acclimated in filtered seawater at in situ temperatures of $3 \pm 1^{\circ} \mathrm{C}$ (East Svalbard) and $6 \pm 1^{\circ} \mathrm{C}$ (Bjørnafjorden) for $24 \mathrm{~h}$. The following treatments were used for all experiments with the copepod species listed below. Either a culture of Thalassiosira antarctica (Expt 1) or natural phytoplankton at in situ concentrations (all other experiments) was provided as food.
Treatment 1 (control): Calanoid copepods were placed in either a 2 or 51 flask with a $400 \mu \mathrm{m}$ mesh size net located $1 \mathrm{~cm}$ above the bottom of the flask. Only the faeces passed through the net. This control was used to assess faecal pellet production rate.

Treatment 2: Same as Treatment 1, but without the net. The copepods were allowed to reach the faeces they produced. Differences in faecal material volume between this treatment and control were considered to be due to modification by calanoid copepods.

Treatment 3: Same as Treatment 1, but including Oithona similis. Faeces produced by calanoid copepods and individuals of $O$. similis (confirmed by visual observation) were able to pass through the $400 \mu \mathrm{m}$ net. Differences in faecal material volume between this treatment and the control were attributed to ingestion or destruction by $O$. similis.

Preliminary experiments in which individual copepods were incubated per flask showed a wide range in pellet production rate (15 to 78 faeces ind ${ }^{-1} \mathrm{~d}^{-1}$ ). In order to reduce variability per flask, from 4 to 30 copepods were incubated. All experiments were run for $24 \mathrm{~h}$ after which the faeces in each flask were collected on a $50 \mu \mathrm{m}$ mesh sieve, preserved with formalin and subsequently sized and counted under a stereomicroscope Wild M8. Only calanoid faeces were considered; cyclopoid faecal pellets are much smaller, hence easy to distinguish. The number of faeces counted and sized per flask ranged from 32 (4 individuals of Temora longicornis) to 651 (30 of Calanus glacialis).

Expt 1. Calanus glacialis (CV) and Oithona similis (adults): Copepods were collected at Stn 112 (East Svalbard, 18 July), and allowed to defecate in 51 containers. A total of 30 Calanus glacialis (Treatments 1, 2 and 3) and 600 . similis (only Treatment 3 ) were maintained in each vessel. Each treatment had 4 replicates; food was a culture of Thalassiosira antarctica $\left(10 \mu \mathrm{g} \mathrm{chl} \mathrm{a}^{-1}\right)$.

Expt 2. Calanus finmarchicus (CV), and Oithona similis (adults): Copepods were collected at Stn 5 (Bjørnafjorden) on 2 occasions: during 'low' in situ chl a concentration (1.1 $\mu \mathrm{g} \mathrm{I}^{-1}, 26$ A.pril 1992) and 'high' in situ chl a concentration (2.2 $\mathrm{g} \mathrm{g}^{-1}, 1$ May 1992). Copepods were maintained in 21 containers at in situ temperature and food levels (natural phytoplankton). A total of 6 calanoid copepods (in Treatments 1, 2 and 3) and 16 (26 April) or 30 (1 May) Oithona similis (only Treatment 3) were used. Each treatment had 9 replicates.

Expt 3. Temora Iongicornis and Oithona similis (adults): Adult females of Temora longicornis were collected at Stn 5 (Bjørnafjorden), and maintained in $2 \mathrm{l}$ containers at in situ temperature and food levels

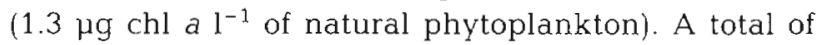
4 calanoid copepods (Treatments 1,2 and 3) and 16 Oithona similis (only Treatment 3) were used. Each treatment had 9 replicates. 
Expt 4. Influence of varying Oithona similis numbers on faecal pellets produced by 6 calanoids: Two batches of experiments were conducted, the first with 6 Temora longicornis (adult females) and the second with 6 Calanus finmarchicus (CV). Treatment 1 was the control in each experiment and in Expt $4 \mathrm{a}$ was accompanied by 7 series of Treatment 3 , each with 6 $T$. Iongicornis but with increasing numbers of Oithona similis $(2,6,20,30,40,60,80$ individuals $)$ in the vessels (3 replicates). All specimens were collected at Stn 5 (Bjørnafjorden), and maintained in 2 l flasks at in situ temperatures $\left(6 \pm 1^{\circ} \mathrm{C}\right)$ with natural plankton $(1.0 \mu \mathrm{g}$ chl a $1^{-1}$ ) as food. In Expt $4 \mathrm{~b}$ with $C$. finmarchicus, 3 series of Treatment 3 were run with 6, 20 and 40 $O$. similis each ( 3 replicates). Specimens were also from Stn 5 but collected on a different day from those in Expt $4 \mathrm{a}_{i}$ chlorophyll a concentrations here were $1.5 \mu g l^{-1}$.

Statistics. Statistical analysis of data was carried out using a non-parametric test: Spearman rank correlation (r) (Zar 1984).

\section{RESULTS}

\section{Field observations along the eastern Svalbard shelf transect}

The longitudinal transect that extended from the northern Barents Sea across the eastern Svalbard shelf and into the border of the Nansen Basin (Fig. 1) covered not only different water masses but, as it was conducted during rapid retreat of the ice cover, also different stages in development of the pelagic regime. The marginal ice zone (MIZ), characterised by patchy ice cover which increased in density from south to north, extended from Stn 119 to Stn 138. Chlorophyll concentrations in the 2 northernmost stations under fairly dense ice cover (Stns 108 and 112) were low $\left(0.3 \mathrm{mg} \mathrm{m}^{-3}\right)$ but conspicuous mats of the diatom Melosira arctica hanging from the undersurface of the ice must have provided food as evidenced by contents of the faecal pellets. The spring bloom was at its height in the northern MIZ with chlorophyll concentrations in the upper $30 \mathrm{~m}$ layer ranging between 1 and $4 \mathrm{mg} \mathrm{m}^{-3}$ (Stns 119 to 124). Similar values were found in the 30 to $50 \mathrm{~m}$ depth layer further south although surface values were 2 to 5 times lower. Diatoms contributed substantially to biomass at Stns 119 to 126 whereas colonies of Phaeocystis sp. dominated at all stations. Indeed, the marked subsurface chlorophyll maxima at Stns 134 to 138 were due almost entirely to Phaeocystis $\mathrm{sp}$. At the 2 southernmost stations (Stns 143 and 146) chlorophyll values were generally considerably below $1 \mathrm{mg} \mathrm{m} \mathrm{m}^{-3}$
Calanus glacialis and C. hyperboreus dominated calanoid biomass at the northern and central stations. C. finmarchicus, Metridia longa and Pseudocalanus elongatus were also frequently found throughout but the former species was much more abundant in the southern stations influenced by Atlantic water (Fransz 1992). Oikopleura sp. was the dominant larvacean. Zooplankton stocks along the transect varied widely; however, the most abundant species at all stations was clearly Oithona similis (Fig. 2). Calanoid copepod and larvacean stocks from the southernmost Stn 146 are not included because of problems with the net; however, as faecal matter and Oithona spp. were collected with another net, their stocks have been depicted.

\section{Volume and $\mathrm{C}$ and $\mathrm{N}$ content of zooplankton faeces}

Calanoid copepod faeces collected from the water column were cylindrical and ranged in size from 39 to $156 \mu \mathrm{m}$ diameter and 290 to $1000 \mu \mathrm{m}$ length. Larvacean faeces were ellipsoidal and highly variable in size with a diameter range of 46 to $289 \mu \mathrm{m}$ and a length range of 86 to $1156 \mu \mathrm{m}$. Because of the wide range in size of individual faeces, the carbon and nitrogen content normalised to volume is presented in Table 1 . The higher carbon content of copepod faeces may be due to greater compaction but also a greater percentage of undigested food. The surprising degree of consistency (low SDs) in each batch of values may be explained by the facts that only the largest faeces were selected and that the animals collected for each measurement came from the same water column or at least general area and hence had the same history of feeding.

\section{Standing stock in the upper $100 \mathrm{~m}$ layer of the transect}

The depth distribution ( 0 to $50 \mathrm{~m}, 50$ to $100 \mathrm{~m}, 100$ to $300 \mathrm{~m}$ ) of recognisable faecal matter was recorded at Stn 124 . More than $70 \%$ of all faecal matter was concentrated in the upper $50 \mathrm{~m}$ depth stratum with very low concentrations below $100 \mathrm{~m}$ depth. Hence, only the upper $100 \mathrm{~m}$ layer is considered here. The amount of faecal material (volume $\mathrm{m}^{-3}$ ) separated into calanoid and larvacean faeces together with zooplankton stocks (ind. $\mathrm{m}^{-3}$ ) are presented as histogrammes in Fig. 2. No obvious relationship between calanoid faeces volume and producer stock size is apparent. The residence times of recognisable faecal material in the water column - calculated from calanoid faeces volume and the estimated daily rate of faecal production (by volume) of only the calanoid copepod stock - are presented with the chlorophyll stock in the $100 \mathrm{~m}$ water column in Fig. 3. The daily faecal volume pro- 

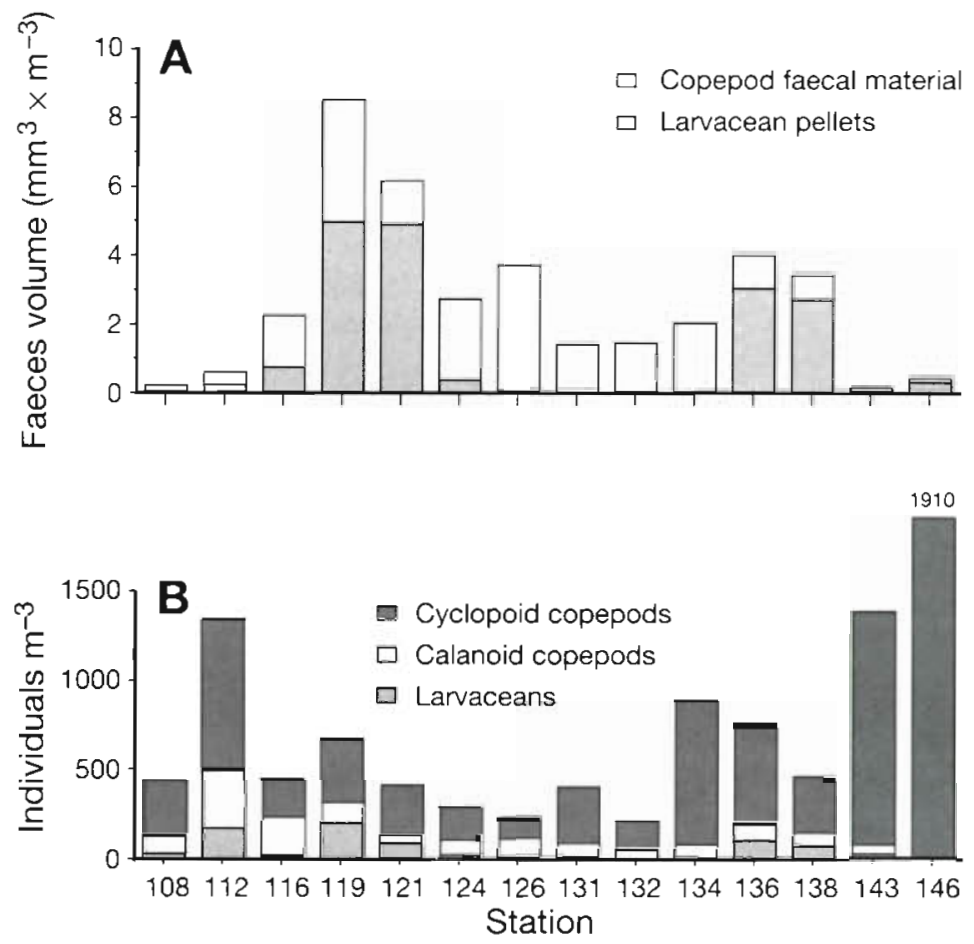

Fig. 2. (A) Faecal material volume of calanoid copepod and larvacean origin in the upper $100 \mathrm{~m}$ of the water column. (B) Abundance of cyclopoids (mainly adults of Oithona similis), calanoids (mainly CIII to CV of Calanus finmarchicus and C. glacialis) and larvacea (mainly Oikopleura $\mathrm{sp}$.) in the upper $100 \mathrm{~m}$ of the transect along the eastern shelf of Svalbard chlorophyll stocks will increase residence times to more realistic values in the range of those calculated for intermediate stations (Fig. 3). The larvaceans and their faeces have not been included as their egestion rates were not examined here. The small faeces produced by Oithona similis have also not been considered.

In Table 2 the standing stocks integrated for the upper $100 \mathrm{~m}$ of chlorophyll, recognisable faecal matter (of calanoid copepods and Oikopleura sp.) in volume and carbon (the latter converted from volume using factors derived from this study and given in Table 1) potential calanoid faeces production rates (see above) have been compared with the stocks of Oithona spp. The maximum potential removal rates of faecal matter by Oithona spp. were calculated from its respective stock multiplied by the average removal rate $\left(5.8 \mathrm{\mu m}^{3} \times 10^{6} \mathrm{ind}^{-1} \mathrm{~d}^{-1}\right.$ derived from Expt 1; see Tabie 4). The measured volume and calculated carbon of all recognisable faecal material collected by the drifting trap from the 3 stations where it was deployed are also presented. For reasons explained below, the removal rate of faecal material by Oithona spp. represents maximum potential values; they are presented in this duction rate was obtained by multiplying the respective calanoid stocks with a faecal material production rate of $30 \times 10^{6} \mathrm{\mu m}^{3}$ ind.-1 $^{-1} \mathrm{~d}^{-1}$ (average of Expts 1 and $2 \mathrm{~b}$; see Table 4 ). The higher production values have been chosen because they were obtained at food concentrations in the same range as found in the MIZ although Expt. 2 was conducted in Bjørnafjorden. Using lower production rates at stations with lower table to provide a rough comparison between production rates by calanoids (also maximum values) and loss rates due to removal and sinking.

The stocks of Oithona similis, calanoid copepods and larvaceans (all in numbers) were compared with the stocks of calanoid faecal material (volume) and larvacean faeces (nos. and volume) in the water columns of all stations by Spearman rank correlation. A sig-

Table 1 Carbon and nitrogen content per volume and $\mathrm{C} / \mathrm{N}$ ratios of faecal pellets defecated after capture by zooplankters collected from the eastern Svalbard shelf and the Bjørnafjorden (Norway). 'Copepods' in the latter case are a mixture of Calanus finmarchicus and Temora longicornis, larvaceans are Oikopleura sp. and Fritillaria sp. The euphausiid faeces were collected in a sediment trap

\begin{tabular}{|c|c|c|c|c|c|}
\hline $\begin{array}{l}\text { Faecal pellets } \\
\text { from: }\end{array}$ & $\begin{array}{l}\text { Carbon content } \\
\left(\mathrm{mg} \mathrm{C} \mathrm{mm}^{-3}\right)\end{array}$ & 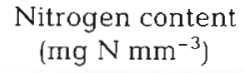 & $\begin{array}{c}\mathrm{C} / \mathrm{N} \\
\text { (by atoms) }\end{array}$ & $\mathrm{n}$ & Source \\
\hline \multicolumn{6}{|l|}{ Barents Sea } \\
\hline Calanus finmarchicus & $0.061 \pm 0.004$ & $0.008 \pm 0.001$ & 6.5 & 4 & Present study \\
\hline Calanus glacialis & $0.038 \pm 0.006$ & $0.006 \pm 0.002$ & 5.4 & 4 & Present study \\
\hline Oikopleura sp. & $0.029 \pm 0.002$ & $0.004 \pm 0.008$ & 6.2 & 4 & Present study \\
\hline \multicolumn{6}{|l|}{ Bjørnafjorden } \\
\hline Copepods & $0.057 \pm 0.01$ & - & - & 5 & González et al. (1994) \\
\hline Larvaceans & $0.042 \pm 0.007$ & - & - & 4 & González et al. (1994) \\
\hline Euphausiids & $0.016 \pm 0.003$ & - & - & 2 & González et al. (1994) \\
\hline Mean & $0.048 \pm 0.03$ & $0.007 \pm 0.004$ & & & \\
\hline
\end{tabular}




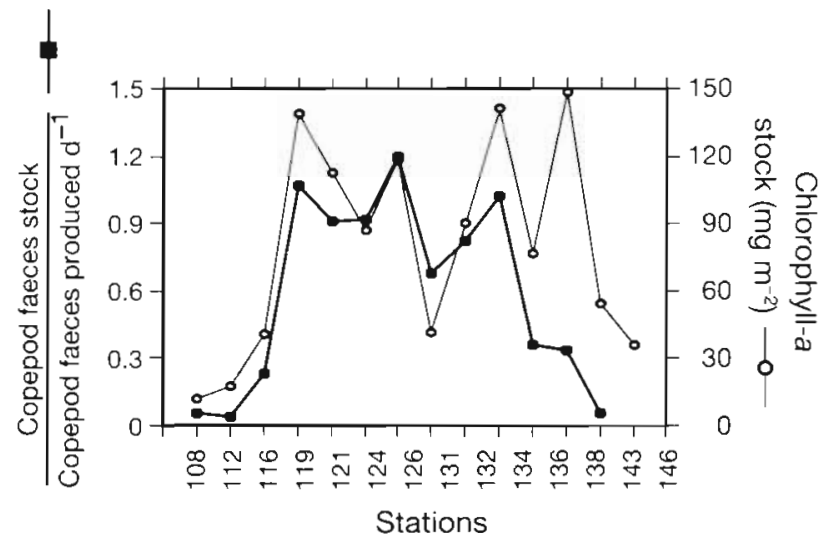

Fig. 3. Standing stock of chl a $\mathrm{m}^{-2}$ compared with residence time of calanoid faecal matter volume in the upper $100 \mathrm{~m}$. Residence time was calculated from suspended faecal volume and faecal production rate $\left(30 \times 10^{6} \mu^{3}\right.$ ind $\left.^{-1} \mathrm{~d}^{-1}\right)$ derived from this study

nificant negative correlation was obtained between $O$. similis numbers and calanoid faecal volumes $(\mathrm{r}=-0.636$ with $p=0.02, n=14$ ) but none with either larvacean faeces volume or number. No correlation was found between calanoid numbers and their faeces volume: $\mathrm{r}=0.11(\mathrm{n}=13)$. However, highly significant positive correlations between larvacean numbers and their faeces were found (numbers: $r=0.819, n=13$; volume: $r=0.897, n=13)$

\section{Experiments on removal rate of faecal material}

The results obtained with these experiments will be biased for the following reasons. One is that although faecal material is indeed ingested by copepods, their feeding activity also results in disintegration of intact faeces into very small pieces that are unrecognisable as faecal material. Hence, counting faecal material can well be subjective although consideration of only those particles retained by a $50 \mu \mathrm{m}$ sieve reduces bias somewhat. During this investigation, all counts were carried out by the same person (H.G.) making the results intercomparable. Further, analysis of 5 samples passed through the $50 \mu \mathrm{m}$ sieve showed that no recognisable faeces fragments were present. This suggests that the fate of the 'missing' faecal material was indeed ingestion. However, we prefer to use the neutral term 'removal rate' which covers both ingestion as well as disintegration into unrecognisable fragments. When only the impact on vertical flux is considered, the differentiation is probably not very important.

Other sources of bias are inherent to experiments carried out in flasks. Thus, faeces and individuals of Oithona similis accumulated on the bottom where the encounter probability was greatly increased. Furthermore, copepod concentrations in the flasks were higher than those normally present under natural conditions. Hence, swimming activity might have con-

Table 2. A comparison of Oithona spp. numbers and their maximum faecal volume and carbon removal rates with standing stocks of suspended zooplankton faecal material in volume and carbon together with potential calanoid faeces production rate and chlorophyll a integrated for the upper $100 \mathrm{~m}$ layer from the transect depicted in Fig. 1a. Daily faecal sedimentation rates estimated from trap collections from 3 stations are included. See text for further details

\begin{tabular}{|c|c|c|c|c|c|c|c|c|c|c|c|c|c|c|}
\hline Stn: & 108 & 112 & 116 & 119 & 121 & 124 & 126 & 131 & 132 & 134 & 136 & 138 & 143 & 146 \\
\hline $\begin{array}{l}\text { Abundance of } \\
\text { Oithona spp. (ind. } \mathrm{m}^{-2} \text { ) }\end{array}$ & 31500 & 84900 & 21300 & 36000 & 27900 & 18400 & 12200 & 31500 & 15200 & 82400 & 57600 & 31200 & 130200 & 191000 \\
\hline $\begin{array}{l}\text { Maximum faecal pellet } \\
\text { removal }\left(\mathrm{mm}^{3} \mathrm{~m}^{-2} \mathrm{~d}^{-1}\right)\end{array}$ & 182.7 & 492.4 & 123.5 & 208.8 & 161.8 & 106.7 & 70.8 & 182.7 & 88.2 & 477.9 & 334.1 & 181.0 & 755.2 & 1107.8 \\
\hline $\begin{array}{l}\text { Maximum faecal pellet } \\
\text { removal (mg C } \mathrm{m}^{-2} \mathrm{~d}^{-1} \text { ) }\end{array}$ & 8.77 & 23.63 & 5.93 & 10.02 & 7.77 & 5.12 & 3.40 & 8.77 & 4.23 & 22.94 & 16.04 & 8.67 & 36.25 & 53.17 \\
\hline $\begin{array}{l}\text { Total faecal material } \\
\text { standing stock }\left(\mathrm{mm}^{3} \mathrm{~m}^{-2}\right)\end{array}$ & 21.5 & 60.5 & 222.7 & 852.7 & 615.8 & 272.7 & 371.1 & 141.4 & 144.6 & 202.9 & 400.7 & 342.5 & 1.5 .3 & 42.8 \\
\hline $\begin{array}{l}\text { Total carbon in faecal } \\
\text { material }\left(\mathrm{mg} \mathrm{m}^{-2}\right)\end{array}$ & 1.03 & 2.90 & 10.69 & 40.93 & 29.56 & 13.09 & 17.81 & 6.79 & 6.94 & 9.74 & 19.23 & 16.44 & 0.73 & 2.05 \\
\hline $\begin{array}{l}\text { Sedimented faecal } \\
\text { material }\left(\mathrm{mm}^{3} \mathrm{~m}^{-2} \mathrm{~d}^{-1}\right)\end{array}$ & 26.7 & 29.6 & - & - & - & 170.4 & - & - & - & - & - & - & - & - \\
\hline $\begin{array}{l}\text { Sedimented faecal } \\
\left.\text { material (mg C m } \mathrm{m}^{-2} \mathrm{~d}^{-1}\right)\end{array}$ & 1.28 & 1.42 & - & - & - & 8.18 & - & - & - & - & - & - & - & - \\
\hline $\begin{array}{l}\text { Calanoid copepod } \\
\text { faecal pellet production } \\
\text { rate }\left(\mathrm{mm}^{3} \mathrm{~m}^{-2} \mathrm{~d}^{-1}\right)^{d}\end{array}$ & 305.0 & 988.2 & 640.5 & 332.5 & 1.37 .3 & 256.2 & 302.0 & 201.3 & 170.8 & 195.2 & 268.4 & 219.6 & 173.9 & - \\
\hline Chl a stock $\left(\mathrm{mg} \mathrm{m}^{-2}\right)$ & 11.5 & 17.0 & 40.3 & 138.7 & 14.9 & 87.0 & 117.8 & 41.3 & 89.6 & 140.7 & 76.5 & 148.4 & 54.1 & 35.6 \\
\hline
\end{tabular}


tributed to break-up of pellets, although the fragments would nevertheless have been recorded (see above). For these reasons our results represent maximum faeces removal rates.

The results of all 4 experiments (Table 3 ) in which Oithona similis was maintained together with different calanoid copepod species (Treatments 1 vs 3) showed a highly significant pattern: the presence of $O$. similis always resulted in a substantial volume loss of calanoid faecal material equivalent to $24,58,56$ and $70 \%$ for the Expts $1,2 a, 2 b$ and 3 respectively. When only calanoids were allowed access to their faeces (Treatments 1 vs 2) none or only negligible removal occurred in Expts $2 \mathrm{~b}$ and 3 but 18 and $24 \%$ of the volume was lost in Expts 1 and 2 respectively. The marked difference in Calanus finmarchicus behaviour in Expts 2a and $2 \mathrm{~b}$ may be related to food supply. In Expt 2b, where food concentrations were double those of Expt. 2a, about 4 times as many pellets were produced and calanoids did not utilise their own pellets. The significantly smaller pellet sizes in Expt 2a compared to Expt $2 \mathrm{~b}$ also indicates that food supply for $C$. finmarchicus in Expt 2 a was below the saturation level and a possible reason why pellets were removed here by calanoids. However, such a relationship apparently did not hold for C. glacialis in Expt 1 , where despite very high food availability, $18 \%$ of the faecal pellets produced were removed by the calanoids. Again, this finding does not necessarily contradict the above explanation because 5 times as many calanoids were confined in the experimental flasks as in the Expts $2 \mathrm{a}$ and $2 \mathrm{~b}$. Whatever the reasons for differences in calanoid utilisation of their own pellets, it is clear that the removal rate by $O$. similis was independent of the chlorophyll concentration.

The production and removal rates of faecal material per individual calanoid copepod and Oithona similis respectively are presented in Table 4. Apart from the fact that different calanoid species were used for the experiments, food concentrations and the 0 . similis/ calanoid ratio varied widely. The highest removal rate was found in Expt 1 where also the highest production rate of faecal material occurred. Possibly, this value is above the saturation value for removal rate by $O$. similis. On the other hand, when supply of faecal material was low (Expts 2a and 3) removal rates were also low but about the same amount of faecal material

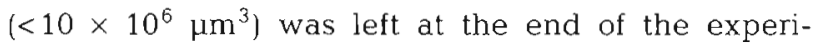
ments. This is probably a residual value inherent to the experimental design which, by comparing rates with each other, results in delay between faeces production by the calanoids and interception by $O$. similis. Thus, the lower removal rates in Expts $2 \mathrm{a}$ and 3 might be due to lower supply rate of faecal material to O. similis.

Another interesting result was the significant shift in size-frequency distribution to smaller sizes in Expt 1, the experiment in which sufficient faecal matter was left over to make this assessment. The average volumes of individual faecal material in Treatments 1,2 and 3 were $1.70 \pm 1.0,1.06 \pm 0.7$ and $1.11 \pm 0.9 \times 10^{6} \mu^{3}$ respectively. This result is not an experimental artefact

Table 3. Results of the experiments with different calanoid copepods and Oithona similis. For details see text. C glac: Calanus glacialis; C. finm.: C. finmarchicus; T. long: Temora longicornis; Thalass.: Thalassiosira antarctica

\begin{tabular}{|c|c|c|c|c|c|}
\hline Treatment & $\begin{array}{l}\text { No. of cal. } \\
\text { copepods }\end{array}$ & $\begin{array}{l}\text { No. of } \\
\text { Oithona }\end{array}$ & $\begin{array}{l}\text { Vol. of faecal material } \\
\qquad\left(\mu \mathrm{m}^{3} \times 10^{6} \mathrm{~d}^{-1}\right)\end{array}$ & $\begin{array}{l}\text { No. of faecal } \\
\text { pellets }\end{array}$ & $\mathrm{n}$ \\
\hline \multicolumn{6}{|c|}{ Expt 1: C. glac./Oithona fed on Thalass. $\left.(10 \mu \mathrm{g} \mathrm{chl} \mathrm{a}]^{-1}\right)$} \\
\hline 1 & 30 & - & $831 \pm 120$ & $816 \pm 114$ & 4 \\
\hline 2 & 30 & - & $679 \pm 150$ & $674 \pm 140$ & 4 \\
\hline 3 & 30 & 60 & $481 \pm 100$ & $464 \pm 88$ & 4 \\
\hline \multicolumn{6}{|c|}{ Expt 2a: C. finm. Oithona fed on natural assemblages of plankton $\left(1.1 \mu \mathrm{g} \mathrm{chl} \mathrm{a}^{1^{-1}}\right)$} \\
\hline 1 & 6 & - & $45 \pm 11$ & $64 \pm 15$ & 9 \\
\hline 2 & 6 & - & $34 \pm 11$ & $63 \pm 17$ & 9 \\
\hline 3 & 6 & 16 & $8 \pm 2$ & $15 \pm 6$ & 9 \\
\hline \multicolumn{6}{|c|}{ Expt 2b: C. finm./Oithona fed on natural assemblages of plankton $\left(2.2 \mu \mathrm{g} \mathrm{chl} \mathrm{a} \mathrm{l}^{-1}\right)$} \\
\hline 1 & 6 & - & $201 \pm 9$ & $191 \pm 14$ & 9 \\
\hline 2 & 6 & - & $202 \pm 32$ & $193 \pm 30$ & 9 \\
\hline 3 & 6 & 30 & $89 \pm 24$ & $85 \pm 23$ & 9 \\
\hline \multicolumn{6}{|c|}{ Expt 3: T. long. Oithona fed on natural assemblages of plankton $\left(1.3 \mu \mathrm{g} \mathrm{chl} \mathrm{a} \mathrm{l}^{-1}\right)$} \\
\hline 1 & 4 & - & $23 \pm 3$ & $45 \pm 6$ & $\theta$ \\
\hline 2 & 4 & - & $21 \pm 7$ & $40 \pm 13$ & 9 \\
\hline 3 & 4 & 16 & $6 \pm 2$ & $12 \pm 5$ & 9 \\
\hline
\end{tabular}


Table 4. Faeces production and removal rates by calanoid copepods and Oithona similis calculated on an individual basis for each experiment. For details see text. Abbreviations as in Table 3

\begin{tabular}{|c|c|c|c|c|}
\hline $\begin{array}{c}\text { Faecal volume } \\
\text { produced } \\
\left(\mu^{3} \times 10^{6} \text { ind }^{-1} \mathrm{~d}^{-1}\right)\end{array}$ & $\begin{array}{c}\text { Faeces } \\
\text { production } \\
\text { (faeces ind } .^{-1} \mathrm{~d}^{-1} \text { ) }\end{array}$ & $\begin{array}{l}\text { Faecal vol. loss } \\
\text { due to calanoid } \\
\qquad\left(\mu m^{3} x\right.\end{array}$ & $\begin{array}{l}\text { Faecal vol. loss } \\
\text { due to Oithona } \\
\left.\mathrm{d} \cdot^{-1} \mathrm{~d}^{-1}\right)\end{array}$ & $\mathrm{n}$ \\
\hline \multicolumn{5}{|c|}{ Expt 1: C. glac./Oithona fed on Thalass, $\left(10 \mu \mathrm{g} \mathrm{chl} \mathrm{a1^{-1 } )}\right.$} \\
\hline $27.7 \pm 4.0$ & $27.2 \pm 3.8$ & $5.1 \pm 5.0$ & $5.8 \pm 1.6$ & 4 \\
\hline \multicolumn{5}{|c|}{ Expt 2a: C. finm. Oithona fed on natural assemblages of plankton $\left(1.1 \mu \mathrm{g} \mathrm{chl} \mathrm{al^{-1 }}\right)$} \\
\hline $7.5 \pm 1.8$ & $10.7 \pm 2.5$ & $1.7 \pm 1.9$ & $2.3 \pm 0.1$ & 9 \\
\hline \multicolumn{5}{|c|}{ Expt 2b: C. finm./Oithona fed on natural assemblages of plankton $\left(2.2 \mu \mathrm{g} \mathrm{chl} \mathrm{a}^{-1}\right)$} \\
\hline $33.4 \pm 1.4$ & $31.9 \pm 2.3$ & $-0.4 \pm 5.3$ & $3.7 \pm 0.8$ & 9 \\
\hline \multicolumn{5}{|c|}{ 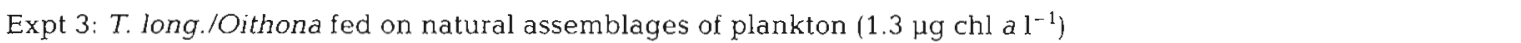 } \\
\hline $5.9 \pm 0.8$ & $11.2 \pm 1.6$ & $0.6 \pm 1.7$ & $1.1 \pm 0.2$ & 9 \\
\hline
\end{tabular}

and can be due to both selective removal of larger pellets but also break-up of pellets not otherwise utilised by both calanoids and $O$. similis.

A clear pattern emerged (Fig. $4 \mathrm{a}, \mathrm{b}$ ) in the experiments in which increasing numbers of Oithona similis were subjected to the same faeces production rate by the calanoid copepods Temora longicornis (Expt 4a) and Calanus finmarchicus (Expt 4b). In Expt $4 \mathrm{a}$, the amount of faecal material that accumulated at the end of the experiment already differed from the control values at cyclopoid/calanoid ratios of 0.3 . The rate of removal of $T$. longicornis faecal material by $O$. similis matched the production rate at cyclopoid/calanoid ratios of $>3$. With increasing $O$. similis numbers, the volume of faecal material left at the end of the experiment did not change (ca $10 \times 10^{6} \mu \mathrm{m}^{3}$ ). This value is similar to those found at the ends of Expts $2 \mathrm{a}$ and 3 and, for reasons discussed above, presumably represents a residual value rather than a lower threshold for faeces utilisation by $O$. similis. The results of Expt $4 \mathrm{~b}$ differed inasmuch as $C$. finmarchicus faeces are about twice as large as those of $T$. longicornis. Daily removal rates by individual $O$. similis at high faecal availability (cyclopoid/calanoid ratios of 1) were the highest recorded $\left(7.7 \times 10^{6} \mu^{3}\right)$ in this study. With increasing 0 . similis density, this rate diminished to 4.5 and $2.7 \times$

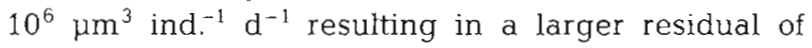

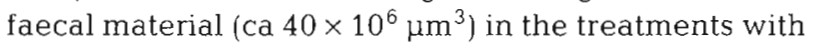
cyclopoid/calanoid ratios of 6.6. The reasons for this are not clear and might have to do with the higher food concentration in the experimental flasks of Expt $4 \mathrm{~b}$ than in Expt 4 a.
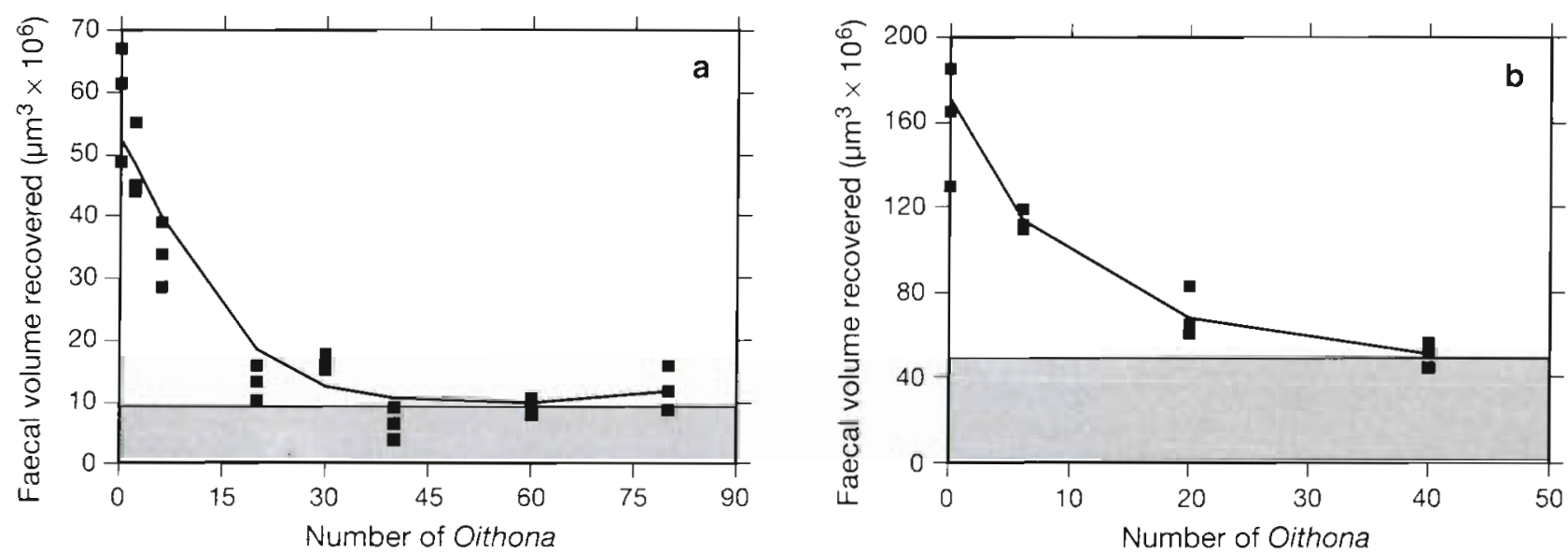

Fig. 4. Volume of faecal material recovered after $24 \mathrm{~h}$ in experiments in which the same number of calanoid copepods were maintained at natural food concentrations but with increasing numbers of adult Oithona similis individuals. In (a) 6 adults of Temora

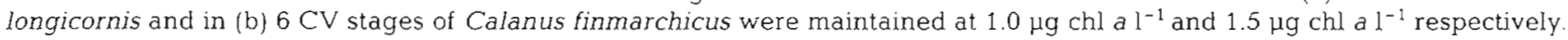
The curve in each case is a least-squares fit. The shaded area represents a residual value (see text for explanation) 


\section{DISCUSSION}

\section{Field observations}

The standing stocks of calanoid copepods and larvaceans along the transect varied widely and were not related to the phytoplankton stocks. Thus, calanoid copepod stocks tended to be higher at the ice-covered stations located on the northern Svalbard shelf edge and slope. These might have represented populations that had overwintered in deeper water over the shelf slope and had recently entered the surface layer. It is known that the dominant calanoids here-Calanus glacialis and C. hyperboreus - have an affinity for the ice cover and feed on detached ice algae well before initiation of the spring bloom (Conover \& Huntley 1991). The conspicuous diatom mats (Melosira arctica) we observed that were suspended from the ice undersurface could have been a possible food source. In contrast to other metazoans, Oithona was more evenly distributed and the most abundant zooplankter at all stations. Their maximum stocks coincided with the post-bloom situation encountered at the southernmost stations of the transect, whereas their abundance in the bloom stations in the middle and north of the transect was distinctly lower. This trend in distribution can be interpreted with build-up of the Oithona stock during and after the spring bloom, a development well known from other localities (Martens 1976). However, the presence of high Oithona stocks under pack ice in the northern stations indicates that favourable growth conditions must have prevailed for some time there as well. Oithona is known to overwinter and even reproduce under closed ice pack (Pavshtiks 1971, Fransz 1988). Our observations provide further support for the growing body of data that Oithona can indeed reproduce under a wide range of conditions.

The fact that the volume of recognisable calanoid faecal material suspended in the water column was not clearly related to the abundance of their producers is not surprising considering that production and removal rate of faeces vary widely and are not necessarily interdependent. However, a relationship between the ratio of estimated faecal volume production to calanoid copepod numbers with the respective chlorophyll stocks is apparent for most stations (Fig. 3). Since we converted copepod numbers into faecal production rate by multiplying the former with rates derived from the experiments, the ratio is a measure of the residence time of recognisable faecal matter in the $100 \mathrm{~m}$ layer. The faecal pellet production rates we employed compare well with literature values for copepods with sufficient food resources (Marshall \& Orr 1955, Corner et al. 1974, Gaudy 1974). Hence, residence times of about $1 \mathrm{~d}$ can be considered realistic for the bloom Stns 119 to 132 where abundant food was available; the lower values at Stns 136 and 138 might be explained by lower faeces production rates - as Phaeocystis sp. colonies dominated phytoplankton stock - but also higher removal rates due to larger Oithona stocks. The lowest values coincided with the low chlorophyll concentrations present in the 2 pre-bloom and 1 post-bloom stations at both ends of the transect. A similar range of calanoid pellet residence times in the water column was found by Smetacek (1980) during spring and summer in the shallow waters of Kiel Bight, by Bathmann \& and Liebezeit (1986) in the central Baltic and by Bathmann et al. (1987) in the Norwegian Sea.

The negative correlation found between calanoid faecal volume, but not that of larvaceans, and Oithona spp. stocks is interesting. A comparison of the data in Table 2 indicates that the potential maximum removal rate per day of calanoid faecal material by the Oithona spp. population at the 2 northern and southern stations could account for about 5 and 15 times the faecal stock respectively. Thus, the size of the Oithona spp. population could well have been the single most important determinant of the stock of calanoid faecal matter in the upper $100 \mathrm{~m}$ layer. The lack of a relationship between Oithona spp. and larvacean faeces, but highly significant correlations between larvaceans and their faeces, seems to indicate that larvacean faeces were not utilised by Oithona spp. However, these conclusions have to be treated with some care considering the many other factors, such as sinking, that control stocks of zooplankton faecal matter in the water column.

The role of sinking in depleting faecal material was not adequately covered as the trap was only deployed 3 times, not enough to hazard a budgetary analysis of faecal stocks given the high degree of variability in the relevant rates and also collection efficiency of shallow traps. As mentioned above, it should also be remembered that the trap will have collected faecal fragments more effectively than the net. The amount of faecal material collected per day by the 3 trap deployments was about half the standing stock in the water column and, at the bloom Stn 124, about 3 times the potential removal rate by the comparatively small Oithona spp. stock. At the 2 northernmost stations the amounts collected by the traps were only a few percent of the potential production rate and much less than the potential removal rate by the large Oithona spp. stock. However, at the bloom Stn 124, the potential production rate was about equal to the potential Oithona spp removal rate plus the amount collected by the trap.

The depth distribution of faecal material recorded at the time station clearly showed that only a small percentage of the standing stock traversed the 100 to $300 \mathrm{~m}$ layer, and the bulk was retained within the upper $50 \mathrm{~m}$ layer. Similar depth distributions were 
reported for faeces of small copepods (Smetacek 1980) Calanus finmarchicus (Krause 1981, Bathmann 1986, Bathmann et al. 1987), Pseudocalanus elongatus (Bathmann 1984) and Euphausia superba (González 1992). If sinking were the only fate of faeces produced by surface-feeding zooplankton, one would expect a uniform concentration with depth. To our knowledge such a depth distribution has not been observed so far which suggests that the bulk of the faeces are indeed retained within the surface layer. Studies in which suspended pellet stocks and production rates were compared with sediment trap catches show that $99 \%$ (Bathmann et al. 1987) and 98 to $78 \%$ (González et al. 1994) of the pellets did not sink out. Microbial breakdown of copepod pellets, particularly at low temperatures, takes more than several days (Honjo \& Roman 1978, Jacobsen \& Azam 1984); hence, removal by metazooplankton remains the most likcly fatc of faccal material in the upper layer.

\section{Implications for Oithona ecology}

A noteworthy result of the experiments with 3 different calanoid copepod species in combination with Oithona similis was that the latter always removed much more faecal material per individual than the producers themselves. The role of cyclopoids in removing calanoid faeces has, to our knowledge, not been studied specifically so far. Studies conducted by Paffenhöfer \& Strickland (1970), Paffenhöfer \& Knowles (1979), Lampitt et al. (1990) and Noji et al. (1991) indicate that not only do calanoid copepods ingest their own faeces but they also break them up. Paffenhöfer \& Van Sant (1985) showed that faecal pellets were not preferentially ingested by Eucalanus. Our results indicate that calanoid utilisation of their faeces varies and might be dependent on the availability of alternative food (phytoplankton). Thus, in Expts 1 and 2a faeces were removed, but not in the other experiments. In Expt 1,30 individuals of Calanus glacialis were confined in $5 \mathrm{l}$ flasks. At clearance rates reported in the literature (e.g. Paffenhöfer \& Van Sant 1985), all phytoplankton was probably eaten before the end of the experiment, resulting in utilisation of faeces. This might also have been the case in Expt 2a.

The experimental results suggest that Oithona and, by inference, other members of the ubiquitous cyclopoid copepods, are probably more specialised for coprophagy than the calanoids, as significant amounts of calanoid faeces were removed independent of the food concentrations. Indeed, the second highest faeces removal rates were recorded in the experiment with Calanus glacialis where a culture of Thalassiosira antarctica $\left(10 \mu \mathrm{g} \mathrm{chl} \mathrm{a} \mathrm{l}^{-1}\right)$ provided an abundant alternative food source, at least in the first half of the experiment. Each $O$. similis individual removed about $20 \%$ of the faecal matter produced by each C. glacialis individual (Expt 1). At lower initial food concentrations with C. finmarchicus (Expt 2a), this ratio increased to $30 \%$, whereby practically all faeces produced were removed by $O$. similis. In contrast, the results of Expt $2 \mathrm{~b}$ appear not to lie in this trend as each $O$. similis individual removed only $10 \%$ of the faeces produced by each $C$. finmarchicus when these were produced at 5 times higher rates than in Expt 2a. The low removal rates recorded in Expt 3 with Temora longicornis are probably due to the low supply rate, as almost all pellets were removed. However, in Expt $4 \mathrm{a}_{1}$ in which $T$. longicornis was also used, $1 \mathrm{O}$. similis removed $75 \%$ of the faeces production of 1 calanoid at an $O$. similis/calanoid ratio of 0.3 . With increasing ratios, the percentage removed per $O$. similis steadily decreased indicating that removal rate is a function of production. The fact that $T$. longicornis pellets are only half the size of those of $C$. glacialis and C. finmarchicus probably explains the higher removal rate.

How do the faecal material removal rates derived from the experiments compare with total food requirements of Oithona similis if we assume removal to equal ingestion? Using the maximum rates obtained from experiments where sufficient faeces were available and converting faecal volume into carbon from conversion factors derived from our measurements, we estimate that about $0.3 \mu \mathrm{g} \mathrm{C}$ was ingested per $O$. similis per day. From the data on carbon content recorded over an annual cycle by Martens (1976) we assume that an average $O$. similis contains about $2 \mu \mathrm{g} C$. Again, literature data indicate that Oithona spp. consumes from 35 to $50 \%$ of its body carbon per day (Lampitt \& Gamble 1982, Drits \& Semenova 1984). It follows that, at a maximum, about 20 to $30 \%$ of the daily carbon requirements of $O$. similis were met by faecal matter, assuming that assimilation efficiency of faecal matter is similar to that of living food, which is, of course, unlikely. That zooplankton faeces can be of nutritional value particularly when food is abundant and assimilation efficiency low is widely recognized (Beklemishev 1962, Cowey \& Corner 1966, Angel 1984). The pellets we measured were collected from calanoids that had fed in the wild. The $\mathrm{C} / \mathrm{N}$ ratios of 5.4 to 6.5 were similar to those of their food, hence did not indicate selective assimilation of $\mathrm{N}$ vs $\mathrm{C}$. However, the $\mathrm{C}$ content on a volume basis was about half that of organisms. This lower $\mathrm{C}$ content might merely reflect degree of compaction of the pellet but it might also be due to empty and crushed diatom frustules. In any case faeces will be of inferior quality as a food source on a volume basis. 
Our results indicate that a significant effect on residence times of calanoid faeces can be expected at cyclopoid/calanoid ratios $>0.3$. At ratios above 4 , practically all pellets produced by calanoids will probably be utilized. In the area studied by us, the cyclopoid/calanoid ratio was always higher than 1 and averaged 4.2 (1.0 to 12.9 ). The lowest ratios were found under spring bloom conditions. Ratios reported by Dam et al. (1993) for the spring bloom in the $\mathrm{N}$ Atlantic $\left(47^{\circ} \mathrm{N}\right)$ were on average $0.42 \pm 0.25$ with a tendency for this ratio to increase from late April to late May. Their highest value was 1.1. Dagg et al. (1982) found consistently higher ratios in the Bering Sea in May with values ranging between 0.7 and 2.8 and an average of $2.0(\mathrm{n}=14)$. Values reported from the Southern Ocean range between 1.4 and $2.7(n=10)$ (Hopkins et al. 1993, Fransz et al. unpubl.) with one exceptionally high value (18) recorded by the latter authors from the WeddellScotia-Confluence. Hopkins \& Torres (1988) reported values of 5.0 to 6.5 in the northwestern Weddell Sea. In the upwelling system off Mauritania, Kuipers et al. (1993) found mean Oithona/calanoid ratios of $8.1 \pm 7.4$, $\mathrm{n}=16$ ). As such, under natural conditions, Oithona is generally sufficiently abundant to utilise a significant portion of calanoid faeces. However, as explained in the 'Results', Oithona similis in the experiments collected pellets from the bottom of the flasks. It is hence worthwhile speculating on how cyclopoids encounter faecal pellets under natural conditions.

Paffenhöfer (1993) pointed out that cyclopoid copepods can not generate feeding currents. Their rather lethargic behaviour indicates that they do not forage actively; hence, encounter with food will depend on movement of the food particles whereby food recognition is either by tactile or chemical cues or by the copepod jumping occasionally to locate a food-rich environment (Paffenhöfer 1993). The successful culture of species of the genus Oithona with motile phytoplankton (Uchima \& Hirano 1986, Paffenhöfer 1993) suggests that this genus may use tactile cues to track motile prey. Faecal pellets (and marine snow aggregates) represent passive - but not stationary - particles in the water column as they have sinking rates in the range of 20 to $200 \mathrm{~m} \mathrm{~d}^{-1}$ (Small et al. 1979, Turner \& Ferrante 1979, Urrere \& Knauer 1981, Fowler \& Knauer 1986, Alldredge \& Silver 1988). The swimming speeds of motile protists are ca 0.2 to $1.0 \mathrm{~mm} \mathrm{~s}^{-1}$ (Fenchel 1987), i.e they cover about 15 to $90 \mathrm{~m} \mathrm{~d}^{-1}$. No doubt, the micro-scale turbulence in the wake of a sinking particle, if at all detectable, will differ significantly from that of a moving organism. However, for a passive planktonic raptor such as Oithona, the encounter rates for moving prey and sinking faeces will be in the same range whereby capture efficiency may be higher in the latter case. Dagg (1993) suggests that sinking aggregates are an important nutritional source in the large calanoid copepod Neocalanus cristatus and that these are possibly sensed by means of long plumes attached to the antennae and urosome.

As detrital particles including faeces are likely to leach more dissolved organic compounds into the surrounding environment (Jumars et al. 1989) than living organisms, they will leave stronger chemical cues in their vicinity for chemosensory phagotrophs to find them. Whether or not cyclopoid copepods have evolved chemoreception for food detection is unknown. Paffenhöfer \& Van Sant (1985) found that longrange chemoreception governs particle capture and short-range chemoreception at the mouth governs particle ingestion in the calanoid copepod Eucalanus pileatus. Possibly, Oithona too has developed chemoreception for locating faecal matter.

Knowledge of cyclopoid feeding habits is sparse and somewhat contradictory. On the basis of gut content analyses and laboratory feeding experiments, Oithona has been considered as herbivorous, carnivorous or omnivorous by different authors (reviewed by Turner 1986, Paffenhöfer 1993 and references therein). In contrast to calanoid copepods, the dominant components of faecal pellets of cyclopoid copepods generally did not mirror those of available phytoplankton assemblages (Turner 1986). This would not have been the case if calanoid faeces constituted an important part of cyclopoid diet. However, reworking of calanoid pellet contents together with ingestion of other food particles would result in a different composition of gut and faecal pellet content than in the case of suspension feeding calanoids. Reviewing the literature on cyclopoid diet, Paffenhöfer (1993) states that 'no clear picture emerges about which types of food particles may be preferred in the natural environment'. Our results suggest that calanoid faeces are indeed utilised although not more than about $30 \%$ of the daily food requirement is from this source, regardless of its availability. Thus, in our experiments the removal rate of faeces by Oithona similis was more or less independent of the chlorophyll concentration.

Circumstantial evidence from the field indicates that Oithona can subsist and reproduce entirely from zooplankton faeces. The evidence was collected during a late winter cruise to the ice-covered Weddell Sea where Oithona was present with eggs (Fransz 1988) in the virtual absence of food (plankton and POC) in the water column (Scharek et al. in press). However, krill was abundant on the ice undersurface and feeding on ice algae (Marschall 1988). The only source of food in the water column would have been the rain of faeces from krill defecating at the ice undersurface. Presumably, the reproducing Oithona population was dependent on this source of organic carbon. 


\section{Implications for vertical flux}

The contribution of zooplankton faeces to vertical flux of particulate matter varies widely (Angel 1984, Corner et al. 1986, Bathmann et al. 1987, Small et al. 1987, Lampitt et al. 1990, Ayukai \& Hattori 1992) and is apparently not a simple function of the standing stock of metazooplankton. However, pulses of faecal matter have been collected in sediment traps (Bathmann et al. 1987, 1991, Peinert et al. 1987), or by filtration of large volumes of water from discrete depths (Bathmann 1984, 1986, Bathmann et al. 1987) or observed sinking through the pycnocline (Krause 1981) indicating that, at least on occasion, a sizeable fraction of the pellets produced does indeed sink out of the surface layer. This degree in variability of faecal flux is hence more likely to be related to the ecology of the surface layer than to physical factors influencing sinking rate through the water column. As faecal pellet production by copepods is clearly a function of food supply (Marshall \& Orr 1966) one would expect the greatest fallout of faeces to occur during bloom periods as a steadily increasing flux of faeces over a period of several weeks. However, the pulse-like nature of faecal fluxes suggests that factors retaining faecal material in the surface layer are at least as important as the production rate.

Coprophagy by copepods has been suggested by Paffenhöfer \& Knowles (1979), Smetacek (1980) and Hofmann et al. (1981) to explain disappearance of copepod faeces from the water column. These authors and Smetacek \& Pollehne (1986) have speculated on the beneficial impact of this behaviour on the different life stages of the copepod population. These speculations have received additional support recently by the work of Lampitt et al. (1990) and Noji et al. (1991) who observed that, in addition to coprophagy, calanoid copepods break-up and shred the surfaces of their own pellets which they term coprorhexy and coprochaly respectively. An important result of this manipulation is to prolong the residence time of faeces within the surface layer and thus fuel the microbial network (Smetacek et al. 1990). The resulting build-up in protozoan biomass could well increase the food supply of the copepods but in particular that of the nauplii. In our experiments coprorhexy was also observed and was presumably due to both calanoids as well as Oithona. However, the degree to which calanoids removed their own faeces was highly variable in contrast to Oithona which always removed a significant fraction of the faeces.

We speculate that the ubiquity of the genus Oithona, its continuous presence in the surface layer and behavioural features auch as lethargy, longevity and opportunistic reproduction coupled with raptorial feeding appendages (Paffenhöfer 1993) are all linked to its ability to utilise a wide variety of particles ranging from phytoplankton and microzooplankton to faeces and other detrital particles in the water column whereby the latter may well form an important part of their diet. We suggest that they use chemical cues to track and capture sinking faecal matter. The other common cyclopoid genus Oncaea, which tends to occupy the layer below that of Oithona - 100 to $200 \mathrm{~m}$ depth - seems to play a similar scavenging role as it has been observed to feed on sinking larvacean houses (Alldredge 1972, Alldredge \& Silver 1988) and is probably also capable of intercepting sinking marine snow and faeces (Skjoldal \& Wassmann 1986). These 2 cyclopoid genera may well consitute a 'coprophagous filter' that can gear its 'mesh size' to the faecal flux emanating from suspension feeding zooplankters. The pulses of faecal matter occasionally collected by traps would then be a result of 'leaks' in the 'filter' that could be caused by patchiness in horizontal distribution or local decimation of the scavengers by predators. Swarms of horizontally migrating zooplankters such as krill would 'swamp' the 'filter' and also result in pulses of faecal matter (Bodungen 1986). We suggest that marine cyclopoids may well play an important role in regulating vertical flux of particles in the sea. Oithona would then be an important part of the retention system operating in the surface layer postulated by Peinert et al. (1989), whereas Oncaea possibly occupies a similar niche in the adjoining deeper layer, where, as Banse (1990) has pointed out, most of the particles sinking from the surface layer are degraded. The fact that Oithona faeces are much smaller than those of calanoids (Martens 1978) and hence will sink more slowly will also contribute to retardation of vertical flux.

The freshwater genus Cyclops is much more active and predatory in its behaviour than its lethargic marine relative Oithona ( $\mathrm{T}$. Weisse pers. comm.). Indeed, because the faeces of the dominant pelagic crustacea in freshwater - daphnids - disintegrate quickly as they are not released in compact pellets (Lampert 1987), a coprophagic niche such as that occupied by marine cyclopoids might not be present in freshwater. Presumably, in contrast to marine calanoid faeces, those of daphnids are utilised only by the microbial network. This difference in behaviour between limnic and marine zooplankton might well be of importance in determining the magnitude of flux through microbial and metazoan pathways and hence the structure of food webs in the respective pelagic systems.

Oithona tends to slip through the meshes of the standard zooplankton nets (Fransz 1988), thus depriving itself of the attention our study indicates it to deserve. 
We suggest that investigations of the factors influencing the relationship between faeces production by suspension feeding zooplankters and coprophagy by raptorial scavengers using direct video observations and under a large variety of conditions will significantly further our understanding of marine food webs and their associated biogeochemical fluxes.

Acknowledgements. We thank U. Bathmann and G. Paffenhöfer for commenting on the manuscript, S. Gonzalez for help during the experiments, E.-M. Nöthig for the chlorophyll values, M. Gleitz for performing carbon analyses and U. Meyer and G. Fransz for providing necessary equipment. Data presented here were collected during the European Polarstern Study II (EPOS II) sponsored by the European Science Foundation and the Alfred-Wegener-Institute for Polar and Marine Research. The International Coccolithophorid Study was sponsored by the Netherlands Institute of Sea Research, Texel. This is publication No. 785 of the Alfred-WegenerInstitute for Polar and Marine Research, Bremerhaven.

\section{LITERATURE CITED}

Alldredge, A. L. (1972). Abandoned larvacean houses: a unique food source in the pelagic environment. Science 177: $885-887$

Alldredge, A. L., Silver, M. W. (1988). Characteristics, dynamics and significance of marine snow. Prog. Oceanogr. 20 : 41-82

Angel, M. V. (1984). Detrital organic fluxes through pelagic ecosystems. In: Fasham, M. J.R. (ed.) Flows of energy and materials in marine ecosystems: theory and practice. Plenum Press, New York, p. 475-516

Ayukai, T., Hattori, H. (1992). Production and downward flux of zooplankton fecal pellets in the anticyclonic gyre off Shikoku, Japan. Oceanol. Acta 15: 163-172

Banse, K. (1990). New views on the degradation and disposition of organic particles as collected by sediment traps in the open ocean. Deep Sea Res. 37: 1177-1195

Bathmann, U. V. (1984). Struktur und Bedeutung des Zooplanktons beim Übergang von der Frühjahrs- zur Sommerphase in der zentralen Ostsee. Diplomarbeit, Univ. Kiel, p. 1-75

Bathmann, U. V. (1986). Zooplanktonpopulationen dreier nordatlantischer Schelfs: Auswirkungen abiotischer und biotischer Faktoren. Ber. Sonderforschungsb. 313, Univ. Kiel 3: 1-93

Bathmann, U. V., Fischer, G., Müller, P. J, Gerdes, D. (1991). Short-term variations in particulate matter sedimentation off Kapp Norvegia, Weddell Sea, Antarctica: relation to water mass advection, ice cover, plankton biomass and feeding activity. Polar Biol. 11: 185-195

Bathmann, U. V., Liebezeit, G. (1986). Chlorophyll in copepod faecal pellets: changes in pellet numbers and pigment content during a declining Baltic spring bloom. P.S.Z.N. I.: Mar. Ecol. 7: 59-73

Bathmann, U. V., Noji, T. T., Voss, M., Peinert, R. (1987). Copepod fecal pellets: abundance, sedimentation and content at a permanent station in the Norwegian Sea in May/June 1986. Mar. Ecol. Prog. Ser. 38: 45-51

Beklemishev, C. W. (1962). Superfluous feeding of marine herbivorous zooplankton. Rapp. p.-v. Réun. Cons. int. Explor. Mer 153: 108-113
Bodungen, B. v. (1986). Phytoplankton growth and krill grazing during spring in the Bransfield Strait, Antarctica - implications from sediment trap studies. Polar Biol. 6: 153-160

Cadée, G. C. (1982). Tidal and seasonal variation in particulate and dissolved organic carbon in the western Dutch Wadden Sea and Marsdiep tidal inlet. Neth. J. Sea Res. 15: $228-249$

Conover, R. J., Huntley, M. (1991). Copepods in ice-covered seas - distribution, adaptations to seasonally limited food, metabolism, growth patterns and life cycle strategies in polar seas. J. mar. Syst. 2: 1-41

Corner, E. D. S., Head, R. N. Kilvington, C. C., Marshall, S. M. (1974). On the nutrition and metabolism of zooplankton. IX. Studies relating to the nutrition of overwintering Calanus. J. mar. biol. Ass. U.K. 54: 319-331

Corner, E. D. S., O'Hara, S. C. M., Neal, A. C., Eglinton, G. (1986). Copepod tecal pellets and the vertical flux of biolipids. In: Corner, E. D. S., O'Hara, S. C. M. (eds.) The biological chemistry of marine copepods. Clarendon Press, Oxford, p. 260-321

Cowey, C. B., Corner, E. D. S. (1966). The amino acid composition of certain unicellular algae, and of the faecal pellets produced by Calanus finmarchicus when feeding on them In: Barnes, H. (ed.) Some contemporary studies in marine science. George Allen and Unwin Ltd, London, p. 225-231

Dagg, M. (1993). Sinking particles as a possible source of nutrition for the large calanoid copepod Neocalanus cristatus in the subarctic Pacific Ocean. Deep Sea Res. 40: 1431-1445

Dagg, M. J., Vidal, J., Whitledge, T. E., lverson, R. L., Goering, J. J. (1982). The feeding, respiration, and excretion of zooplankton in the Bering Sea during a spring bloom. Deep Sea Res. 29: 45-63

Dam, H. G., Miller, C. A., Jonasdottir, S. H. (1993). The trophic role of mesozooplankton at $47^{\circ} \mathrm{N}, 20^{\circ} \mathrm{W}$ during the North Atlantic Bloom Experiment. Deep Sea Res. 40: 197-212

Drits, A. V., Semenova, T N. (1984). Experimental investigations of the feeding of Oithona similis Claus. Oceanology (USSR). 24: 755-759 (English transl.)

Fenchel, T. (1987). Ecology of protozoa. The biology of free-living phagotrophic protist. Springer-Verlag, Berlin, p. $1-197$

Fowler, S. W., Knauer, G. A. (1986). Role of large particles in the transport of elements and organic compounds through the oceanic water column. Prog. Oceanogr. 16: 147-194

Fransz, H. G. (1988). Vernal abundance, structure and development of epipelagic copepod populations of the Eastern Weddell Sea (Antarctica). Polar Biol. 9: 107-114

Fransz, H. G. (1992). Distribution and structure of zooplankton populations. In: Rachor, E. (ed.) Scientific cruise report of the 1991 Arctic expedition ARK VIIL/2 of RV 'Polarstern'. Ber. Polarforsch. 115: 67-73

Gaudy, R. (1974). Feeding of four species of pelagic copepods under experimental conditions. Mar. Biol. 25: 125-14 1

Gauld, D. T. (1966). The swimming and feeding of planktonic copepods. In: Barnes, H. (ed.) Some contemporary studies in marine science. George Allen and Unwin Ltd, London, p. $313-334$

González, H. E. (1992). The distribution and abundance of krill faecal material and oval pellets in the Scotia and Weddell Seas (Antarctica) and their role in particle flux. Polar Biol. 12: 81-91

González, H. E., González, S. R., Brummer, G.-J. A. (1994). Short-term sedimentation pattern of zooplankton, faeces and microplankton at a permanent station in the Bjørnafjorden (Norway) during April-May 1992. Mar. Ecol. Prog. Ser. 105: 31-45 
Hofmann, E. E., Klinck, J. M., Paffenhöfer, G.-A. (1981). Concentrations and vertical fluxes of zooplankton fecal pellets on a continental shelf. Mar. Biol. 61: 327-335

Honjo, S. Roman, M. R. (1978). Marine copepod fecal pellets: production, preservation, and sedimentation. J. mar. Res 36: $45-57$

Hopkins, T. L., Lancraft, T M., Torres, J. J., Donnelly, J. (1993). Community structure and trophic ecology of zooplankton in the Scotia Sea marginal ice zone in winter (1988). Deep Sea Res. 40: 81-105

Hopkins, T. L., Torres, J. J. (1988). The zooplankton community in the vicinity of the ice edge, western Weddell Sea, March 1986. Polar Biol. 9: 79-87

Jacobsen, T. R., Azam, F. (1984). Role of bacteria in copepod fecal pellet decomposition: colonization, growth rates and mineralization. Bull. mar. Sci. 35: 495-502

Jumars, P. A., Penry, D. L., Baross, J. A., Perry, M. J., Frost, B. W. (1989). Closing the microbial loop: dissolved carbon pathway to heterotrophic bacteria from incomplete ingestion, digestion and absorption in animals. Deep Sea Res. 36: $483-495$

Krause, M. (1981). Vertical distribution of faecal pellets during FLEX'76. Helgoländer Meeresunters. 34: 313-327

Kuipers, B. R., Witte, H. J., González, S. R. (1993). Zoolankton distribution in the coastal upwelling system along the Banc d'Arguin, Mauritania. Hydrobiologia 258: 133-149

Lampert, W. (1987). Feeding and nutrition in Daphnia. In: Peters, R. H., de Bernardi, R. (eds.) Daphnia. Mem. Ist. Ital. Idrobiol. 45: 143-192

Lampitt, R. S. (1978). Carnivorous feeding by a small marine copepod. Limnol. Oceanogr. 23: 1228-1231

Lampitt, R. S., Gamble, J. C. (1982). Diet and respiration of the small planktonic marine copepod Oithona nana. Mar. Biol. 66: $185-190$

Lampitt, R. S., Noji, T T., von Bodungen, B. (1990). What happens to zooplankton faecal pellets? Implications for material flux. Mar. Biol. 104: 15-23

Marschall, H.-P. (1988). The overwintering strategy of Antarctic krill under the pack-ice of the Weddell Sea. Polar Biol. 9: 129-135

Marshall, S. M., Orr, A. P. (1955). Experimental feeding of the copepod Calanus finmarchicus (Gunner) on phytoplankton cultures labelled with radioactive carbon $\left({ }^{14} \mathrm{C}\right)$. Deep Sea Res. 3: 110-114

Marshall, S. M., Orr, A. P. (1966). Respiration and feeding in some small copepods. J. mar. biol. Ass. U.K. 46: 513-530

Martens, P. (1976). Die planktischen Sekundär und Tertiärproduzenten im Flachwasserökosystem der westlichen Ostsee. Kieler Meeresforsch. 3: 60-71

Martens, P. (1978). Faecal pellets. Fich. Ident Zooplankton 164: $1-4$

Noji, T T., Estep, K. W., MacIntyre, F., Norrbin, F. (1991). Image analysis of faecal material grazed upon by three species of copepods: evidence for coprorhexy, coprophagy and coprochaly. J. mar. biol. Ass. U.K. 71: 465-480

Paffenhöfer, G.-A. (1993). On the ecology of marine cyclopoid copepods (Crustacea, Copepoda). J. Plankton Res. 15: $37-55$

Paffenhöfer, G.-A., Knowles, S. C. (1979). Ecological implications of fecal pellet size, production and consumption by

This article was submitted to the editor copepods. J. mar. Res. 37: 35-49

Paffenhöfer, G.-A., Strickland, J. D. H. (1970). A note on the feeding of Calanus helgolandicus on detritus. Mar. Biol. 5: $97-99$

Paffenhöfer, G.-A., Van Sant, K. B. (1985). The feeding response of a marine planktonic copepod to quantity and quality of particles. Mar. Ecol. Prog. Ser. 27: 55-65

Pavshtiks, E. A. (1971). Seasonal variations in the number of zooplankton in the region of the North Pole. Dokl. Akad. Nauk SSSR Biol. Sci. 196: 59-62

Peinert, R., Bathmann, U., von Bodungen, B., Noji T (1987). The impact of grazing on spring phytoplankton growth and sedimentation in the Norwegian Current. Mitt. Geol.Paläont. Inst. Univ. Hamburg, SCOPE UNEP, Sonderband 62: 149-164

Peinert, R., Bodungen, B. v., Smetacek, V. (1989). Food web structure and loss rate. In: Berger, W. H., Smetacek, V. S., Wefer, G. (eds.) Productivity of the ocean: present and past. John Wiley \& Sons, Berlin, p. 35-48

Scharek, R., Smetacek, V., Fahrbach, E., Gordon, L. I., Rohardt, G., Moore, S. (in press.) The transition from winter to spring in the eastern Weddell Sea, Antarctica. I. Phytoplankton and suspended matter in the eastern Weddell Gyre. Deep Sea Res.

Skjoldal, H. R., Wassmann, P. (1986). Sedimentation of particulate organic matter and silicium during spring and summer in Lindaspollene, Western Norway. Mar Ecol. Prog. Ser. 30: 49-63

Small, L. F., Fowler, S. W., Ünlü, M. I. (1979). Sinking rates of natural copepod fecal pellets. Mar. Biol. 51: 233-241

Small, L. F., Knauer, G. A., Tuel, M. D. (1987). The role of sinking fecal pellets in stratified euphotic zones. Deep Sea Res. 34: 1705-1712

Smetacek, V. (1980). Zooplankton standing stock, copepod faecal pellets and particulate detritus in Kiel Bight. Estuar. coast. Mar. Sci. 11: $477-490$

Smetacek, V, Pollehne, F. (1986). Nutrient cycling in pelagic systems: a reappraisal of the conceptual framework. Ophelia 26: 401-428

Smetacek, V., Scharek, R., Nöthig, E.-M. (1990). Seasonal and regional variations in the pelagial and its relationship to the life history cycle of krill. In: Kerry, K. R., Hempel, G (eds.) Antarctic ecosystems. Ecological change and conservation. Springer-Verlag, Berlin, p. 103-114

Turner, J. T. (1986). Zooplankton feeding ecology: contents of fecal pellets of the cyclopoid copepods Oncaea venusta, Corycaeus amazonicus, Oithona plumifera and $O$. simplex from the northeastern Gulf of Mexico. P.S.Z.N. I. Mar. Ecol. 7: 289-302

Turner, J. T., Ferrante, J. G. (1979). Zooplankton fecal pellets in aquatic ecosystems. BioSci. 29: 670-677

Uchima, M., Hirano, R. (1986). Food of Oithona davisae (Copepoda: Cyclopoidea) and the effect of food concentration at first feeding on the larval growth. Bull. Plankton Soc. Jap. 33: 21-28

Urrere, M. A., Knauer, G. A. (1981). Zooplankton fecal pellet fluxes and vertical transport of particulate organic material in the pelagic environment. J. Plankton Res. 3: 369-387

Zar, J. H. (1984). Biostatistical analysis. Prentice-Hall, Inc. Englewood Cliffs, NJ

Manuscript first received: December 23, 1993

Revised version accepted: June 28, 1994 